\title{
INDUCTION OF A PROTECTIVE IMMUNE RESPONSE TO MURINE CORONAVIRUS WITH NON-INTERNAL IMAGE ANTI-IDIOTYPIC ANTIBODIES
}

\author{
Mathilde Yu and Pierre J. Talbot \\ Laboratory of Neuroimmunovirology \\ Virology Research Center \\ Institut Armand-Frappier \\ Université Du Québec \\ Laval, Québec, Canada H7N 4Z3
}

\begin{abstract}
Neurotropic murine coronaviruses (MHV) provide an excellent animal model to study experimental modulation of the immune response to a viral pathogen with anti-idiotypic antibodies. It is known that among the various types of anti-idiotypic antibodies (anti-Id), those designated beta $(\beta)$ or internal image can molecularly mimic the antigen and induce biological activities such as anti-viral protection and neutralization. We have recently shown that polyclonal non-internal image anti-idiotypic antibodies of the $\gamma$-type could induce protective anti-coronavirus immunity ${ }^{1}$.

In the present study, a polyclonal anti-Id (Ab2) was induced against a neutralizing murine monoclonal antibody (MAb1), designated 5B170.11. Mice immunized with this affinity-purified rabbit $\mathrm{Ab} 2_{\alpha}$, a non-internal image antibody, were partially protected against lethal infection by the JHM strain of MHV. However, other polyclonal and monoclonal non-internal image Ab2 induced against another neutralizing MAb1, designated 4-11G.6, were not able to protect mice against lethal infection with the A59 strain of MHV.

These results demonstrate that anti-viral protection by altering the idiotypic network with non-internal image-bearing anti-idiotype reagents can be achieved even with some anti-Id of the $\alpha$-type.
\end{abstract}




\section{INTRODUCTION}

Anti-idiotypic antibodies are potentially involved in the regulation of the immune response to a given antigen $(\mathrm{Ag})^{2}$. Moreover, anti-Id have been used to manipulate the immune response in vivo in several experimental systems ${ }^{3,4}$.

Anti-Id (Ab2) are classified in three different categories based on the idiotopes they recognize on $\mathrm{Ab} 1 . \mathrm{Ab} 2_{\alpha}$ recognize idiotopes far from the antigen combining site (paratope) of $\mathrm{Ab} 1 . \mathrm{Ab} 2_{\gamma}$ recognize idiotopes near the paratope of $\mathrm{Abl}$ and can compete with antigen for the binding site of $\mathrm{Abl} . \mathrm{Ab} 2_{\beta}$ are referred to as internal image anti-Id. They have the capacity to mimic the antigen used to generate the Abl and can substitute for antigen in inducing an anti-antigen response because they recognize an idiotype at the level of the paratope. However, the idiotypic network is complex because some non-internal image anti-Id can also induce an immune response to antigen, which can be described as biological rather than a structural mimicry. For example, $\mathrm{Ab} 2_{\alpha}$ could induce an anti-hepatitis B surface $\mathrm{Ag}$ response ${ }^{5}$ and neutralizing antibodies against $\mathrm{HIV}^{6}$. Also, we have described an $\mathrm{Ab} 2_{\gamma}$-induced protective immune response against MHV-A59'. Therefore, non-internal image Ab2 can have interesting biological properties, although we do not yet understand their mechanisms of action.

Neurotropic murine coronaviruses (MHV strains JHM and A59) provide an excellent animal model to study the manipulation of the idiotypic network and its effect on a viral infection.

In the present study, we describe the production and characterization of non-internal image $\mathrm{Ab} 2 \mathrm{~s}$ against in vitro neutralizing and in vivo protective monoclonal antibodies (MAb1) specific to MHV-A59 and MHV-JHM. MAb1 4-11G.6 recognizes a discontinuous epitope on the spike (S) glycoprotein of MHV-A59, whereas MAb1 5B170.11 recognizes a linear epitope on the homologous protein of MHV-JHM. These two MAbl had both been characterized previously and shown to neutralize virus infectivity in vitro and passively protect mice in vivo against a lethal MHV infection ${ }^{7,10}$. This suggested that the $\mathrm{S}$ protein has biological importance in immune protection against MHV infection, which was confirmed by the demonstration that affinity-purified $\mathrm{S}$ glycoprotein could vaccinate against lethal coronavirus infection?

Administration of these $\mathrm{Ab} 2 \mathrm{~s}$ to BALB/c mice showed that some non-internal image $\mathrm{Ab} 2_{\alpha}$ could partially mimic interesting biological properties of internal image $\mathrm{Ab} 2$, such as in vivo protection against viral infection. This emphasizes the complexity of the idiotypic network and how little is known on the mechanisms of induction of a protective immune response by anti-Id.

\section{MATERIALS AND METHODS}

Animals. New-Zealand white female rabbits of 2.5 to $3 \mathrm{~kg}$ were purchased from Ferme de sélection Cunipur, Stukely Sud, Québec, Canada. Four to 5 week-old female $\mathrm{BALB} / \mathrm{c}$ mice were purchased from Charles River, St-Constant, Québec, Canada.

Antibodies. The production and characterization of the hybridoma secreting mouse neutralizing MAb 4-11G.6, specific for a discontinuous epitope on the S glycoprotein of MHV-A59, has been previously described ${ }^{7}$. Monoclonal antibody $5 \mathrm{~B} 170$ is specific for a continuous epitope on the S protein of $\mathrm{MHV}-\mathrm{JHM}^{8}$. All antibodies including normal rabbit immunoglobulins (NRIg) were purified by standard Protein-A-Sepharose chromatography.

Polyclonal anti-Id and antibody assays. The immunization protocols for generating polyclonal anti-Id and their characterization have been described elsewhere ${ }^{1}$, including virus 
neutralization and protection assays and ELISA for detection of Ab3 against MHV-A59 in mice sera. ELISA for detection of idiotype in antiviral sera and of inhibition of binding of idiotype to antigen by anti-Id were also described previously!

Monoclonal anti-Id. The production of MAb was described previously ${ }^{7}$ : BALB/c mice were immunized with $100 \mu \mathrm{g}$ of affinity purified MAb 4-11G.6 and given two booster injections of $50 \mu \mathrm{g}$.

ELISA for detection of MAb2. Microtiter plates were coated with affinity purified $\mathrm{F}\left(\mathrm{ab}^{\prime}\right)_{2} \mathrm{MAbl}[1.25 \mu \mathrm{g} / \mathrm{mL}$ in phosphate buffered saline (PBS) $]$ and incubated for $16 \mathrm{~h}$ at room temperature. The plates were blocked with PBS containing $10 \%(\mathrm{v} / \mathrm{v})$ fetal calf serum and $0.2 \%(\mathrm{v} / \mathrm{v})$ Tween- 20 for $30 \mathrm{~min}$ at $37^{\circ} \mathrm{C}$. Hybridoma culture supernatants (4 days of growth) diluted $1 / 2$ were added to the wells and incubated for $90 \mathrm{~min}$ at room temperature. The plates were then washed five times with PBS containing $0.1 \%(\mathrm{v} / \mathrm{v})$ Tween-20. Peroxidase-labeled goat anti-mouse Fc antibody (ICN Biologicals, Miles) was then added and incubated for $90 \mathrm{~min}$ at room temperature. The plates were washed five times and the reaction was developed with $O$-phenylenediamine and hydrogen peroxide. The reaction was stopped with $1 \mathrm{~N} \mathrm{HCl}$ and the absorbance read at $492 \mathrm{~nm}$ using an SLT EAR 400 AT plate reader.

Virus and cells. MHV-A59 and MHV-JHM were obtained from the American Type Culture Collection (Rockville, MD), plaque-purified twice, and passaged four times at a multiplicity of infection of 0.01 on DBT cells as described previously ${ }^{9}$.

Plaque assays with brain homogenates of mice immunized with anti-Id. Brains were collected 5 days after virus challenge and plaque assays performed as described elsewhere ${ }^{10}$.

Statistics. Results of in vivo protection assays were analyzed with the Kaplan-Meier survival curve ${ }^{11}$. Antiviral Ab3 antibody responses were evaluated at a 1/500 dilution and analyzed with the Mann-Whitney test ${ }^{12}$. Brain viral titers observed after NRIg or anti-Id treatment and the repeated experiments were first analyzed with a Manova test ${ }^{13}$. This test included an interaction test which in our case was shown to be significant, so the two treatments were then compared separately by a Student $t$-test ${ }^{14}$.

\section{RESULTS AND DISCUSSION}

\section{Polyclonal Anti-5B170.11}

A polyclonal anti-Id 5B170.11 was purified by affinity chromatography from the serum of a rabbit immunized with MAb1 5B170.11. To determine if the anti-Id bound to the paratope of MAb1, inhibition of virus-binding by anti-Id was tested. This inhibition of attachment assay can discriminate $\alpha$-type from $\beta$ and $\gamma$-types anti-Id. The polyclonal anti-Id produced against MAb1 5B170.11 did not inhibit the interaction between MAbl and antigen, consistent with it being an $\mathrm{Ab} 2_{\alpha}$ (Fig. 1A). The anti-Id was also tested for it capacity to inhibit the neutralizing ability of MAbl in an inhibition of virus-neutralization assay. As much as $10 \mu \mathrm{g}$ of anti-Id could not reduce the neutralization titer of MAbl (data not shown), which confirmed the results of the inhibition of attachment assay.

On the basis of previous studies showing that non-internal image anti-Id could trigger an antigen-specific immune response $\mathrm{e}^{1,16,17}$ like internal image anti-Id, we examined the in vivo modulation capability of the rabbit polyclonal $\mathrm{Ab} 2_{\alpha}$ anti-5B170.11. Two groups of 6 $\mathrm{BALB} / \mathrm{c}$ mice were immunized with anti-Id or NRIg three times at two-week intervals. After the third injection, the MHV-specific Ab3 response was examined by ELISA. No detectable antiviral antibodies were produced in mice immunized with $\mathrm{Ab} 2_{\alpha}$ (data not shown). To verify whether the $A b 2_{\alpha}$ could nevertheless induce a protective immune response, mice were challenged intracerebrally with $10 \mathrm{LD}_{50}$ of MHV-JHM, 10 days after the last booster anti-Id injection. All mice showed clinical signs of MHV infection. Animals in control groups died 


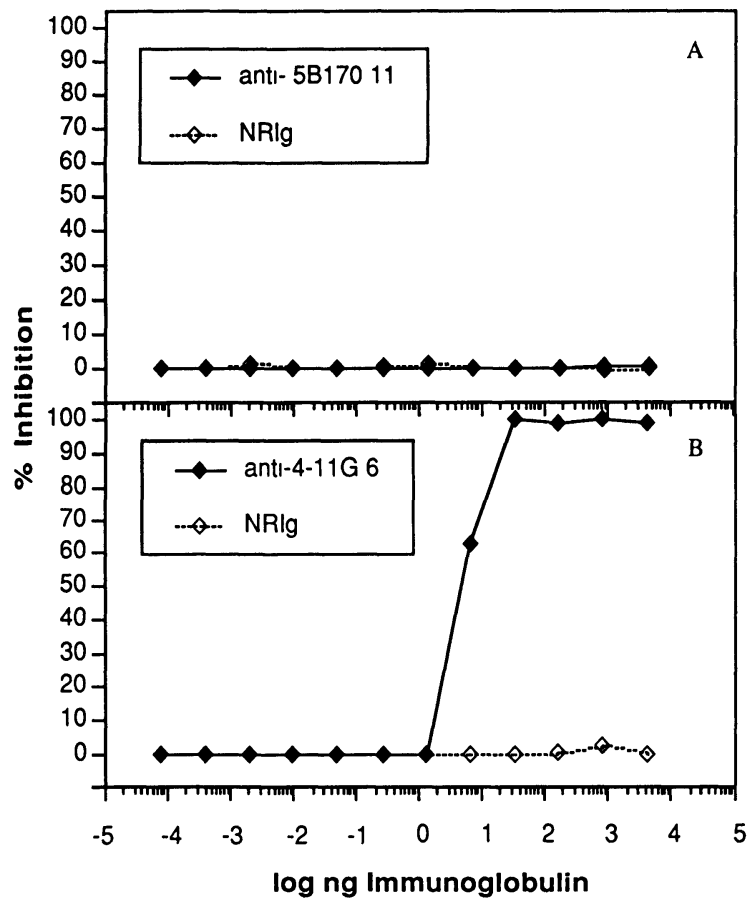

Figure 1. Inhibition of attachment assay for discrimination of $\alpha$-type from $\beta$ and $\gamma$-type ant1-Id Microtiter plates were coated with $5 \mu \mathrm{g} / \mathrm{mL}$ of viral antigen Biotınylated MAb1 and dilutions of purified Ab2 or NRIg were pre-incubated together and transferred onto the viral antigen-coated plates. The residual binding of MAb1 to viral antigens was detected using peroxıdase-labeled streptavidın

from MHV-JHM infection within 6 to 10 days, whereas $16 \%$ to $33 \%$ of mice in the $\mathrm{Ab2} \alpha$ group lived longer (until day 41) (Fig. 2A). In a repeat experiment some mice survived in both control and $\mathrm{Ab} 2_{\alpha}$ treated group (Fig. $2 \mathrm{~B}$ ). In the third repeat experiment, anti-viral Ab3s were detected by ELISA at a dilution of $1 / 500$ (data not shown). The presence of specific $\mathrm{Ab} 3 \mathrm{~s}$ at this dilution was significant for a $\mathrm{p}$ value of 0.0014 in the Mann-Whitney test. However, these Ab3s could not neutralize viral infection in vitro (data not shown). No specific reactivity was observed in control groups (NRIg) or pre-immune sera. We then evaluated whether the apparent partial protection of mice correlated with reduced viral titers

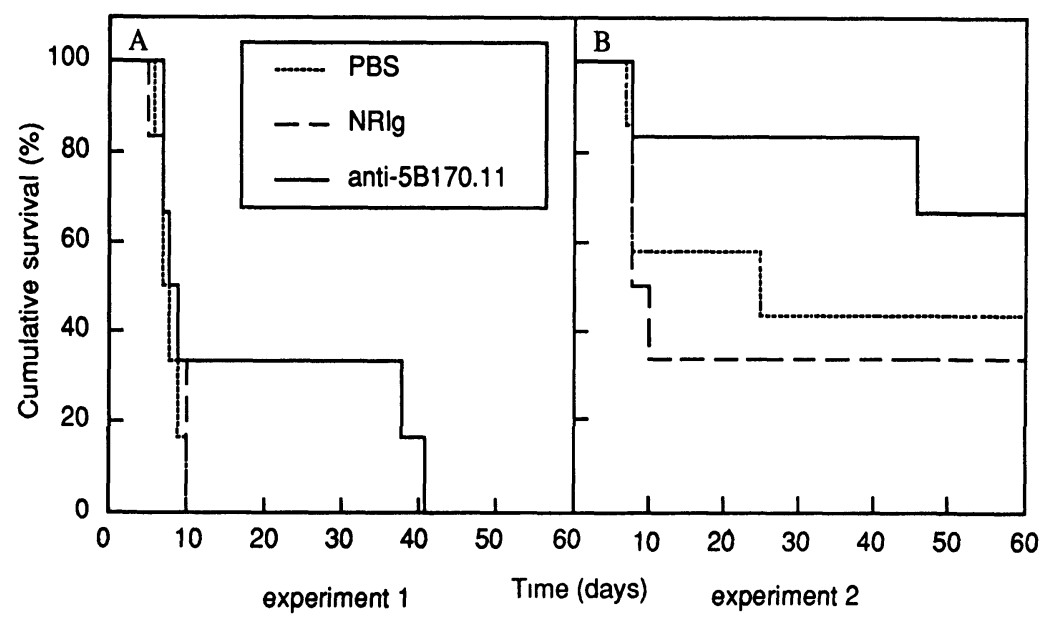

Figure 2. Survival curves of mice immunized with polyclonal Ab2 ant1-5B170.11. Groups of 6 BALB/c mice were immunized with Ab2, NRIg or PBS and challenged with $10 \mathrm{LD}_{50}$ of MHV-JHM. A: experiment 1; B: experıment 2 
Figure 3. Brain viral titers observed after antiId and NRIg treatments Virus titers from brains of mice immunized with Ab2 ant1$5 \mathrm{~B} 17011$ or NRIg were quantitated by plaque assay

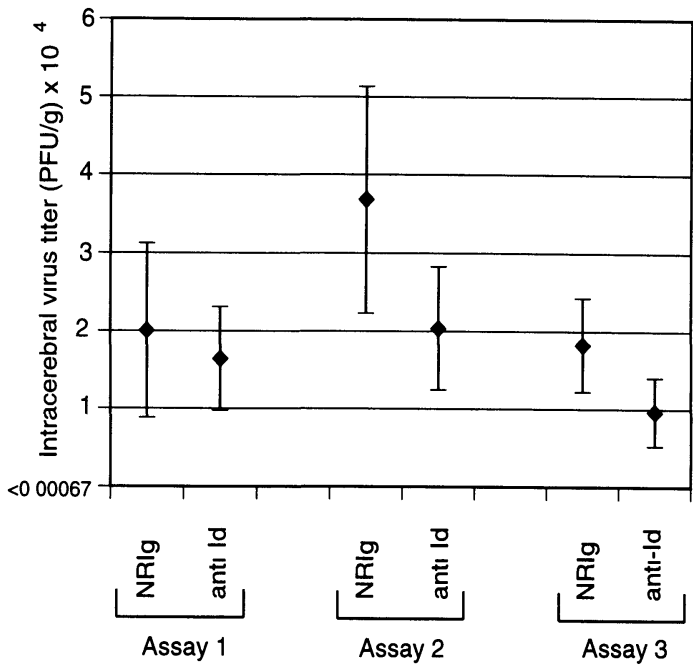

in the brain (Fig 3) The first plaque assay did not show a significant reduction of viral titers but two other plaque assays from the same brain aliquots did show significant reductions in viral titers between mice treated with $\mathrm{Ab} 2_{\alpha}$ and NRIg The reduction in viral titer was significant at a $p$ value of 0014 with the second assay and at a $p$ value of 0004 for the third assay Such reduced viral titers could explain the observed apparent protection

We observed either a weak or non-existent antiviral Ab3 response (data not shown) and variable protection after treatment with polyclonal $\mathrm{Ab} 2_{\alpha}$ ant1-5B170 11 (Fig 2) This suggests either a need to optimize the conditions for antiviral Ab3 induction, or an involvement of cellular protective responses The induction of specific immune responses by $\mathrm{Ab} 2_{\alpha}$ has been studied in different experimental systems s $^{1516171819}$ and the activation of the cellular component of the immune response by ant1-Id was reported 202122

Further experiments are needed to understand the mechanisms involved in the induction of protective immunity by non-internal image ant1-Id For example, very little is known on the interactions between ant1-1diotypic antıbody and immune cells

The reasons why some $\mathrm{Ab} 2_{\alpha}$ induce protection and others do not are unclear $\mathrm{Ab} 2 \alpha_{\alpha}$-1nduced immune responses might be the result of the induction of a regulatory pathway of idiotypes Ant1-Id could induce a different series of immunological reactions within an 1diotypic network than those induced by the antigen

Table 1. Ab2 ant1-4-11G 6

\begin{tabular}{lccccc}
\hline & \multicolumn{5}{c}{ ant1-4-11G 6 } \\
\cline { 2 - 6 } & Polyclonal & MAb2 & MAb2 & MAb2 & MAb2 \\
& $\gamma$ & $\alpha$ & $8-11 G 1$ & $2-10$ F 1 & $7-11$ E 1 \\
\hline Ant1-Id & $<100$ & $<100$ & $<100$ & $<100$ & $<100$ \\
Ab3 $^{\mathrm{a}}$ & $<50$ & $<50$ & $<50$ & $<50$ & $<50$ \\
Neutralizing Ab3 $^{\mathrm{b}}$ & - & - & - & - & - \\
Protection $^{\mathrm{c}}$ & - & - & - & $\alpha$ & $\alpha$ \\
\hline
\end{tabular}

${ }^{a} \mathrm{H} 1 \mathrm{ghest}$ dilution where Ab3 ant1-virus is detectable by ELISA

${ }^{b}$ Reciprocal of the highest dilution of serum that neutralızed $50 \%$ of input virus

${ }^{\mathrm{c}} \mathrm{BALB} / \mathrm{c}$ mice immunized with Ab2 and challenged intracerebrally with MHV-A59 


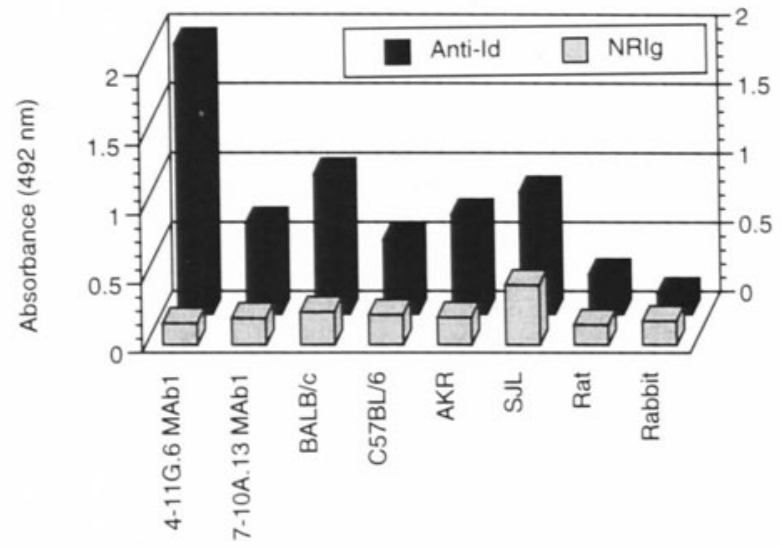

Figure 4. Detection of idiotype by Ab2. Microtiter plates were coated with 1.5 $\mu \mathrm{g} / \mathrm{mL}$ of purified polyclonal Ab2 anti4-11G.6 or NRIg. The binding of syngeneic (BALB/c), allogeneic (C57BL/6, $\mathrm{AKR}, \mathrm{SJL}$ ) and xenogeneic (rat and rabbit) anti-viral sera produced against MHV-A59 was determined by ELISA using peroxidase-labeled species-specific anti-Ig.

\section{Polyclonal and Monoclonal Anti-4-11G.6}

Polyclonal and monoclonal anti-Id were also produced in animals immunized with MAb1 4-11G.6. They are listed in Table 1.

Polyclonal Anti-4-11G.6. As a first approach towards determining whether the polyclonal anti-Id against MAb1 4B11.6 was an internal image $\left(\mathrm{Ab} 2_{\beta}\right)$ anti-Id, its ability to bind to the paratope of MAbl was tested. The results of the ELISA inhibition of attachment assay are shown in Fig.1B. Binding of MAb1 4-11G.6 to viral antigen could be inhibited by purified anti-Id in a dose-dependent manner. Twenty ng of anti-Id was enough to inhibit $100 \%$ of MAb1 binding to antigen, while the same amount of NRIg did not have any effect on this binding, indicating that the polyclonal anti-Id was not an $A b 2_{\alpha}$. The ability of the polyclonal $\mathrm{Ab} 2$ to abrogate the neutralization of virus infectivity was also tested. Ten $\mu \mathrm{g}$ of anti-Id could reduce the neutralization titer of MAb1 by 400 -fold, whereas the same amount of NRIg did not have any effect (data not shown). These results confirmed the ELISA inhibition of attachment assay and suggested that this anti-Id binds at or near the paratope of MAb1 and was therefore an $\mathrm{Ab} 2_{\beta}$ or $\mathrm{Ab} 2 \gamma$. To distinguish between these two possibilities, we investigated the ability of this anti-Id to be recognized by antisera from different animal species raised against the initial antigen. $\mathrm{An} \mathrm{Ab} 2_{\beta}$ should bind to all anti-MHV hyperimmune sera because of its internal image properties. As shown in Fig.4, our polyclonal anti-Id recognized a share idiotype in hyperimmune sera from BALB/c, C57BL/6, AKR and SJL mice. It also bound weakly to rat sera, but not to rabbit sera. These results demonstrated that this anti-Id could not induce antibody responses to the antigen across species barrier. Therefore, this polyclonal anti-Id must only bind near the antigen-binding site of MAb1. This gamma-type reaction was confirmed by the absence of both specific antiviral Ab3 induction and protection (Table 1).

Interestingly, we previously demonstrated that $\mathrm{Ab} 2_{\gamma}$ against $\mathrm{MAbl}$ 7-10A specific for a related epitope could vaccinate mice against infection by this coronavirus ${ }^{1}$. We now show that $\mathrm{Ab} 2_{\gamma}$ anti-4-11G.6 did not induce a protective immune response. MAbs1 7-10A and 4-11G.6 were previously shown to recognize two overlapping conformational epitopes by an ELISA competition assay ${ }^{7}$. Therefore, the mechanisms of protection induced by the $\mathrm{Ab} 2_{\gamma}$ anti-7-10A remain to be investigated.

Monoclonal Anti-4-11G.6. Anti-4-11G.6 MAb2 were also generated in BALB/c mice. They were all of IgG $2 b$ isotype and, as shown in Table 1 , did not compete with antigen 
for binding of MAbl, which suggests that they recognize framework 1diotopes and can be classified as $\mathrm{Ab} 2_{\alpha}$ These MAb2, coupled to KLH to enhance their immunogenicity, did not induce specific antiviral Ab3 nor induced protection against MHV-A59 (Table 1) Previous studies have shown that such Ab2s could induce Ab3s in other viral systems ${ }^{16}{ }^{17}$ However, in the present work, no MAb2 $\alpha$ were able to induce an antiviral Ab3 response

The use of monoclonal anti-Id with interestıng biological activities should help clarify the mechanısms of protection induced by non-internal image ant1-Id Moreover, the production of monoclonal internal image $\mathrm{Ab} 2_{\beta}$, although potentially interesting for characterization of molecular determinants involved in viral pathogenesis, identification of cellular receptors and vaccination, is technically difficult Molecular cloning of the antibody repertoire could overcome this technical problem ${ }^{23}$ Such studies are in progress

\section{ACKNOWLEDGMENTS}

We are grateful to Eduardo Franco and Marie Desy for expert assistance with statistical analyses, Francine Lambert for excellent technical assistance, Alain Lamarre for assistance in the early stages of this work and Michael J Buchmeier (The Scripps Research Institute, La Jolla, CA, U S A) for his generous gift of MAb 5B170 Mathilde Yu acknowledges studentships from the Institut Armand-Frappier and the Fonds pour la Formation de Chercheurs et l'Alde a la Recherche (FCAR) and Pierre J Talbot scholarship support from the Fonds de la Recherche en sante du Quebec (FRSQ) This work was supported by a grant from the Medical Research Council of Canada (MRC) to P J T

\section{REFERENCES}

1 Lamarre, A, Lecomte, J, Talbot, P J 1991 Antıdıotypic vaccination agaınst murıne coronavirus infection J Immunol 147 4256-4262

2 Jerne, N K 1974 Towards a network theory of the immune system Ann Immunol 125c 373-389

3 UytdeHaag, G C M , Bunschoten, H, Weıjer, K, Osterhaus, A D M E 1986 From Jenner to Jerne Towards idiotypic vaccines Immunol Rev 90 93-113

4 Zhou, E -M , Chanh, T C, Dreesman, G R, Kanda, P, Kennedy, R C 1987 Immune response to human immunodeficiency virus In vivo adminıstration of anti-1diotype induces an antı gp 160 response specific for a synthetic peptide J Immunol 139 2950-2956

5 Kennedy, R C, Eıchberg, J W, Lanford, R E, Dreesman, G R 1986 Antı-1dıtypıc antıbody vaccine for type B viral hepatitıs in chimpanzees Science 232 220-223

6 Fung, M S C, Sun, C R Y, Liou, R S, Gordon, W, Chang, N T, Chang, T -W, Sun, N -C 1990 Monoclonal antı-1diotypıc antıbody mımıckıng the principal neutralızation site in HIV-1 gp120 induces HIV-1 neutralızing antibodies in rabbits J Immunol 145 2199-2206

7 Daniel, C, Talbot, P J 1990 Protection from lethal coronavirus infection by affinity-purıfied spike glycoprotein of murıne hepatitis virus, strain A59 Virology 174 87-94

8 Collıns, A R, Knobler, R L, Powell, H, Buchmeır, M J 1982 Monoclonal antıbodies to murıne hepatıtıs virus-4 (strain JHM) define the viral glycoprotein responsible for attachment and cell-cell fusion Virology 199 358-371

9 Daniel, C, Talbot, P J 1987 Physico-chemical properties of murıne hepatitıs virus, strain A59 Arch Virol 96 241-248

10 Buchmeier, M J, Lewıckı, H A, Talbot, P J, Knobler, R L 1984 Murıne hepatıtıs virus-4 (strain JHM)-induced neurologic disease is modulated in vivo by monoclonal antibody Virology 132 261-270

11 Armitage, P, Berry, G Statistical methods in medical research Second edition, 1987, Blackwell Scientific Publications, Oxford pp 428-433

12 Armitage, P, Berry, G Statistical methods in medical research Second editıon, 1987, Blackwell Scientıfic Publications, Oxford pp 411-412 
13 Tabachnick, B G, Fidell, L S Usıng Multivariate Statıstıcs Second edition, 1989, Harper Collıns Publıshers, Inc, New York p 376

14 Armitage, P, Berry, G Statıstical methods in medical research Second editıon, 1987, Blackwell Scientıfic Publications, Oxford pp 107-111

15 Francotte, M, Urbain, J 1984 Induction of anti-tobacco mosaic virus antibodies in mice by rabbit antıdiotypic antibodies J Exp Med 160 1485-1494

16 Schick, M R, Dreesman, G R, Kennedy, R C 1987 Induction of an anti-hepatitıs B surface antigen response in mice by noninternal image $\left(\mathrm{Ab}_{\alpha}\right)$ anti-1diotypic antibodies $\mathrm{J}$ Immunol 138 3419-3425

17 Zhou, E -M, Lohman, K L, Kennedy, R C 1990 Adminıstration of nonınternal image monoclonal anti-1diotypic antibodies induces idiotype-restricted responses specific for human immunodeficiency virus envelope glycoprotein epitopes Virology 174 9-17

18 Suñe, C, Smerdou, C, Anton, I M, Abril, P, Plana, J, Enjuanes, L 1991 A conserved coronavirus epitope, critical in virus neutralization, mimicked by internal-image monoclonal anti-idiotypic antibodies J Virol 65 6979-6984

19 Kang, C -U, Nara, P, Chamat, S , Carall, V, Chen, A, Nguyen, M -L , Yoshıyama, H, Morrow, W J W, Ho, D D , Kholer, H 1992 Ant1-1dıotype monoclonal antibody elıcts broadly neutralızıng antı-gp 120 antıbodies in monkeys Proc Natl Acad Scı USA 89 2546-2550

20 Rees, A D M, Praputpittaya, K, Scoging, A Dobson, N, Ivanyı, J, Young, D, Lamb, J R 1987 T-cell activation by ant1-idiotypic antibody evidence for the internal image Immunology 60 389-393

21 Huang, $\mathrm{J}-\mathrm{H}$, Ward, $\mathrm{R}$ E , Kohler, $\mathrm{H} 1986$ Idiotope antigens $\left(\mathrm{Ab} 2_{\alpha}\right.$ and $\left.\mathrm{Ab2}{ }_{\beta}\right)$ can induce in vitro $\mathrm{B}$ cell proliferation and antibody production $J$ Immunol 137 770-776

22 Zhou, S-R, Whitaker, J N 1993 Specific modulation of T cells and murıne experimental allergic encephalomyelitis by monoclonal ant1-1diotypic antibodies J Immunol 150 1629-1642

23 Marks, J D, Hoogenboom, H R, Griffiths, A D, Winter, G 1992 Molecular evolution of proteins on filamentous phage $J$ Biol Chem 267 16007-16010 